\title{
Minimal Invasive Acromioclavicular Joint Reconstruction (MINAR) módszerrel szerzett tapasztalataink és elért eredményeink acromioclavicularis (AC) ficamoknál
}

\author{
DR. SZABÓ SZABOLCS, DR. BODNÁR ÉVA, DR. OCZELLA EMESE RÉKA, \\ DR. URBÁN FERENC
}

\section{ÖSSZEFOGLALÁS}

Az acromioclavicularis ízület sérülésének konzervatív és mútéti ellátása lehetséges. A Rockwood IVVI-os típusoknál mútéti ellátás indokolt. A szerzők osztályán korábban többnyire az AC ízület percutan áttúzését és Bosworth csavarozását végezték. A szerzők az elért eredményekkel, hasonlóan a nemzetközi véleményekhez, elégedetlenek voltak, emiatt került sor új módszer „felkutatására”, majd bevezetésére. A választás a "Minimal Invasive Acromioclavicular Joint Reconstruction” (MINAR) módszerre esett. A technikával szerzett tapasztalatok és eredmények korrelálnak a nemzetközi irodalomban közöltekkel. A kezdeti két problémás eset után nagyon jó klinikai eredményt találtak. A MINAR az AO elveknek is megfelelően biztosít anatómiai rekonstrukciót. Biomechanikai szempontból ideális, mert az AC ízület eredeti mozgásait és a korai funkcionális kezelést lehetővé teszi. A technika minimálisan invazív, a rendszer rendkívül erős, de dinamikusan stabil. A mútét könnyen elsajátítható, a mútéti idő rövid, a beteg számára nem jelent nagy terhelést. Szövődménymentes esetekben további mútétekre (implantátum eltávolítás) nincs szükség.

\section{Kulcsszavak: $\quad$ Acromioclavicularis ízület; Ficam; Minimál invaziv technika;} Rekonstruktiv sebészet; Vállficam; Varrat-technika;

Sz. Szabó, É. Bodnár, E. R. Oczella, F. Urbán: Minimal Invasive Acromioclavicular Joint Reconstruction (MINAR) of acromioclavicular (AC) joint dislocations: experiences and results

$A C$ joint injuries can be managed either nonoperatively or with surgery. Operative treatment is recommended in case of Rockwood type IV-VI AC joint dislocations. In the past few years at the Traumatology and Hand Surgery Department of BAZ University County Teaching Hospital, Miskolc, Hungary favoured surgical techniques were percutaneous K-wire or Bosworth screw fixation. During this time, among the international findings, the doctors at the authors' department were discontent with the radiological and clinical outcome, this resulted in finding a new technique and bringing it into practice. MINAR technique seemed like a good choice. Experience with the technique and the results were consistent with the international literature published one. After the initial two problematic cases very good clinical results were found. This procedure in accordance with the AO principles provided anatomical reconstruction. It is biomechanically ideal, because allows free range of AC joint motions and early mobilisation. In addition, this technique is minimally invasive, the system is extremely strong but at the same time dynamically stable. The operation can be easily acquired, duration of surgery is short, and also minimally stressful for the patient. In uncomplicated cases implant removal is not required.

Keywords: $\quad$ Acromioclavicular joint - Surgery; Joint dislocations - Surgery;

Minimally invasive surgical procedures - Instrumentation;

Reconstructive surgical procedures - Instrumentation;

Shoulder disclocation - Surgery; Suture anchors; 


\section{BEVEZETÉS}

A vállövi sérülések körülbelül 9-10\%-a jár az acromioclavicularis ízület sérülésével (12). A sérülés súlyossága a szalagok (lig. acromioclaviculare - AC, lig. conoideum, lig. trapezium, utóbbi kettő coracoclavicularis - CC - szalagok), valamint az ízületi tok és a deltotrapezoid fascia sérülésétől függ. Ezt korábban Tossy, majd később Rockwood klasszifikálta. Jelenleg a klinikai gyakorlatban utóbbi beosztását használjuk. Ennek alapja a clavicula dislocatiójának mértéke, iránya és a szalagok sérülése. A Rockwood I-es típusnál a szalagok (nagyrészt) épek, az ízületi tok érintett, II-es típusban a tok-szalag rendszer sérül, de a CC szalagok jól tartanak. A Rockwood III-VI-os ficamoknál már AC, CC szalagsérülés, jelentős clavicula dislocatio áll fenn, utóbbi gyakran töréssel szövődött. Rockwood I-II-es típus konzervatívan kezelendő $(2,7)$. Rockwood III-as ficamnál (elmozdulás kisebb, mint 100\%, maximum 2,5 cm-es coracoclavicularis távolság) nincs egységes konszenzus. A nemzetközi irodalom szerint jobb kozmetikai eredmény érhető el mütéttel, funkció szempontjából azonban a konzervatív kezelésnek nincs hátránya, ezért inkább a konzervatív kezelést preferálják $(3,8)$. Rockwood IV-es (horizontális elmozdulás) és V-ös (elmozdulás 300\%-ig, coracoclavicularis távolság nagyobb, mint $2,5 \mathrm{~cm}$ ) ficamnál a delta és trapézizomról a clavicula leszakad, operatívan kezelendő. A Rockwood VI-os ficam rendkívül ritka, ezzel saját tapasztalatunk nincs, a processus coracoideus alá került claviculát az irodalom szerint operatívan kell kezelni $(6,15)$.

Az összes AC ficam körülbelül $96 \%-a$ Rockwood I-III - ebből 58\% Rockwood I-II - a többi 4\% IV-VI-os ficam (11). Az AC ízületi ficam operatív ellátására számos lehetőség van. Osztályunkon az elmúlt évtizedekben leggyakrabban az AC ízületi ficamok fedett repozícióját és percutan tűzését, vagy Bosworth csavarozást végeztünk, illetve ezek kombinációját. Alig néhány esetben helyeztünk be Hook lemezt, valamint végeztünk húzóhurkos rögzítést. Az eseteinket áttekintve az irodalomhoz hasonlóan percutan tűzésnél, húzóhuroknál időnként a tűződrót migrációját, törését, redislocatiót (9), gyulladást, Bosworth csavarozásnál a csavar processus coracoideusból való kiszakadását, a csavar törését találtuk.
Ezek a problémák vezettek oda, hogy új, megbízhatóbb mútéti módszert, megoldást keressünk. Az AC ízület biomechanikáját ismerve fontos szempont volt, hogy a körülbelül 40-45 fokos rotációs mozgást és a körülbelül 20 fokos csúszó mozgást meg tudjuk tartani (4). Olyan megoldást kerestünk, amely anatómiai rekonstrukciót, dinamikus stabilitást biztosít, minimálisan invazív $(13,14)$, gyorsan elvégezhető, lehetőleg ne legyen szükség újabb mútétre (fémeltávolítás: túződrót, csavar, Hook lemez) és gyors rehabilitációt tesz lehetővé. A szakirodalom tanulmányozása során találtunk a hazánkban kevéssé elterjedt MINAR technikára, úgy gondoltuk, megfelel a fent támasztott követelményeknek.

\section{ANYAG ÉS MÓDSZER}

A Borsod-Abaúj-Zemplén Megyei Kórház és Egyetemi Oktató Kórház Traumatológiai Osztályán 2014 júniusától alkalmazzuk a MINAR technikát.

\section{Mütéti technika}

Beach chair pozícióban fektetjük a beteget. A fejet megfelelő védelemben kissé az ellenoldal felé húzzuk. Az AC ízülettől körülbelül $3 \mathrm{~cm}$-re medialisan 3-4 cm-es, a claviculára merőleges metszést ejtünk. A deltaizomzatot kissé leválasztva, letolva feltárjuk a processus coracoideust. Laterál felől vezetve a célzást és a lágyrész-védelmet biztosító speciális fúróvezetőt a processus basisára helyezzük, ezzel óvva a medialisan lévő neuromuscularis struktúrát (1. ábra). A védő-vezető segítségével először Kirschner drótot fúrunk át a processus coracoideuson, majd a hüvely eltávolításával, a Kirschner drót mentén 4,5 mm-es fúróval is átfúrjuk a processus coracoideust. A jó pozíció eléréséhez időnként szükség lehet a clavicula dorsal felé nyomására. Előkészítjük az implantátumot, amely az LCA pótlásnál is használt $2 \mathrm{db}$ titán 14 mm-es endobutton lemezből és erős sodrott, nem felszívódó fonálból (1-es Ethibond Excel) áll. A fonalat hurokszerűen az endobuttonokon kétszer átvezetjük. A hurok végén lévő endobuttont a speciális átvezetővel hosszában átdugjuk a fúrt lyukon, majd a fonalakat megemelve megbillentjük az endobuttont és funkcionális próbát végzünk (2. ábra). A clavicula furatát az $A C$ ízülettől körülbelül 
3 cm-re készítjük, ennek helyének meghatározásában segíthet a megemelt, megfeszített fonál, valamint a CC szalag maradványok. Képerősítővel is ellenőrizhetjük a pozíciót, amelyet osztályunkon az első mútéteknél megtettünk. A furat hasonlóan készül, mint a processus coracoideus esetében, lehetőleg a clavicula hossztengelyétől kissé ventral felé, azért, hogy a claviculát ne húzza előre a megfeszített

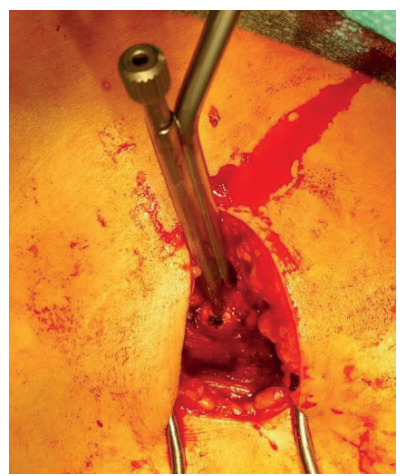

1. ábra Fúrás célzóval

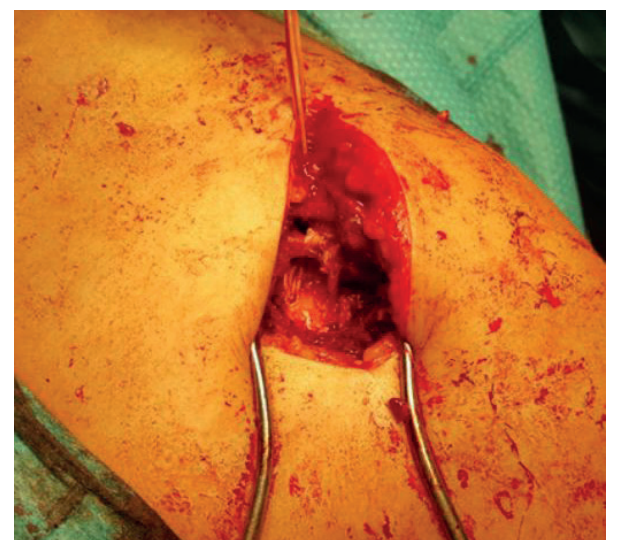

3. ábra Fonalak áthúzása a claviculán implantátum. A claviculán fúrt lyukon fonalat vezetünk át, amellyel az endobuttont áthúzzuk a clavicula cranialis oldalára (3. ábra). Ezt követően a claviculát lenyomva, speciális eszköz segítségével reponálunk, majd váltott jobb-bal kézzel, gyeplőszerű mozdulatokkal a fonalakat megfeszítjük, megcsomózzuk (4. ábra). Stabilitás ellenőrzés után réteges sebzárást végzünk.

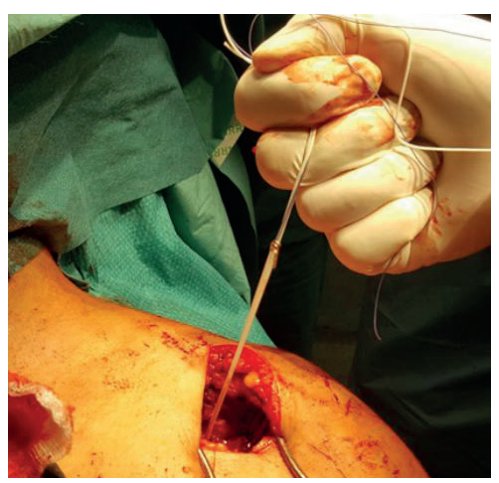

2. ábra Az endobutton clavicula alá vezetése

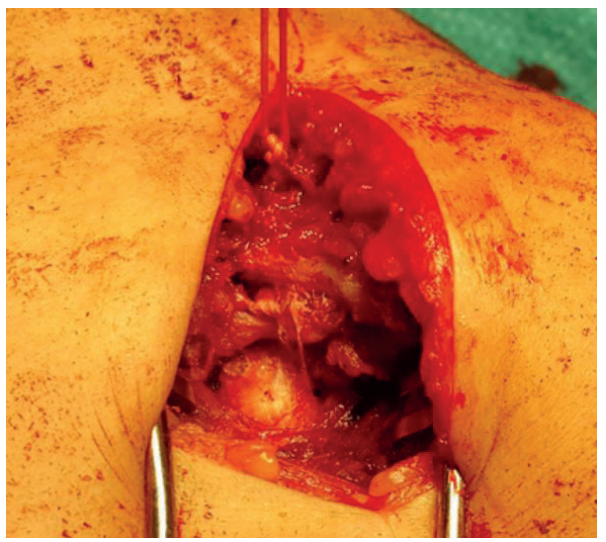

4. ábra Fonalak megcsomózása 


\section{Mútéti indikációk}

- Rockwood III-V.

- Lateralis clavicula vég törése

- Krónikus instabilitás esetén más mútéttel kombinálva

\section{Kontraindikációk}

- a beteg gyenge általános állapota, társult sérülései

- lokális lágyrész infekció, seb

- clavicula test törése

2014. júniusától 2015. december 31-ig 27 beteg AC ficamát rögzítettük MINAR-ral a fenti kritériumoknak megfelelően. Clavicula acromialis vég törés, és krónikus instabilitás esetén más mútéttel kombinálva nem használtuk. Az összes sérülés zárt volt. Az anamnézis felvétel és fizikális vizsgálat után minden esetben összehasonlító antero-posterior irányú váll röntgenfelvétel, horizontális elmozdulás esetén axillaris felvétel is készült. Terheléses röntgenvizsgálatot rutinszerűen sem preoperatíve, sem posztoperatíve nem végeztünk.

A betegek $89 \%$-a ( 24 fő) férfi, a legfiatalabb 19, a legidősebb 59 éves volt (átlagéletkor: 43,17 év). 11\% (3 fő) 35 és 46 év közötti nő volt (átlagéletkor: 40,6 év).

A fentebb említett Rockwood klasszifikációt alapul véve $6(22 \%)$ a III-as , 10 (37\%) a IV-es, 11 (41\%) az V-ös típusba tartozott. A besorolást a coracoclavicularis távolság mérése alapján végeztük. Posztoperatív röntgen minden alkalommal készült. A preoperatívan mért coracoclavicularis távolság átlagosan 18,1 (6-26) mm volt. A vizsgált betegek közül egy volt multitraumatizált, a többieknél izolált sérülés volt az AC ficam. A posztoperatív szakban az eredeti leiratnak megfelelően 3-4 hét nyugalomba helyezést - karfelkötést - javasoltunk háromszög kendőben, de a betegek az ingagyakorlatokat a mútét utáni napon megkezdték (10). A sérülteket 4-6 héttel a mútét után rutinszerűen kontrollvizsgálatra rendeltük vissza, amikor röntgenfelvétel is készült. Egy beteg utókezelését másik megyében, a lakóhely szerint illetékes intézményben végezték. $\mathrm{Az}$ elért eredményeket az Oxford Shoulder Score alapján értékeltük.

\section{EREDMÉNYEK}

Mind a 27 MINAR-ral végzett acromioclavicularis rekonstrukció után készült posztoperatív felvételen a coracoclavicularis távolságot az egészséges oldallal összehasonlítva nem találtunk szignifikáns különbséget, a legnagyobb eltérés maximum $1-2 \mathrm{~mm}$ volt. A posztoperatív coracoclavicularis távolság 18,1 mm-ről átlagosan 8,1 (2-13) mm-re csökkent. A mútéttől számított 4-6 hét múlva készült röntgenfelvételen 8,5 (6-12) mm-es átlagos coracoclavicularis távolságot mértünk. Meg kell jegyeznünk azonban, hogy a röntgenfelvételek nem standard körülmények között készültek, a horizontális síktól történő eltérés befolyásolhatta a mérések pontosságát. Osteolysis nem volt. Három esetben látszott a röntgenfelvételen a coracoclavicularis szalag ossificatiója, ami egyszer sem okozott a betegnek panaszt. Egy alkalommal mútét közben a fonál megfeszítésekor, a clavicula repositiója után, a csomózás közben az implantátum fonala elszakadt. Ezt azonnal észleltük, újabb fonalakat vezettünk át az endobuttonokon, és ezzel sikeresen végeztük el a mútétet. A sérülés és a műtét között eltelt idő átlagosan 5,5 (1-32) nap volt.

Két betegnél volt olyan szövődményünk, amely hosszú távon panaszt okozott, és amelyek után újabb mútétek váltak szükségessé. Az egyik esetben a beteg operált válla 2-3 héttel a primer mútét után vált panaszossá, ekkor ennek radiológiai jele még nem mutatkozott (5. ábra). A MINAR-ral végzett acromioclavicularis rekonstrukció után két hónappal subluxatiót, négy hónappal később az AC ízületben már luxatiót észleltünk (6. ábra). A fonál elszakadt. A dislocatio tovább fokozódott, módszerváltás mellett döntöttünk.

A második esetben a posztoperatív röntgenfelvételen azt észleltük, hogy a processus coracoideus alá helyezett endobutton nem centrális elhelyezkedésű, hanem kissé lateralis pozícióba került (7. ábra). A két hónappal később készült röntgenen az endobutton a processus coracoideust elhagyta és a clavicula alá került. Az AC ízületben fokozatosan Rockwood II-nek megfelelő subluxatio alakult ki. Az acromioclavicularis ízület területe mindvégig érzékeny volt, gyógytorna, szteroidos infiltráció sem szüntette a panaszokat. A MINAR mútétet követő 1 év múlva clavicula vég 
reszekciót végeztünk. A beteg panaszai nem múltak el teljesen, a korábbi AC ízület vetülete érzékeny maradt (8. ábra).

$A z$ elért klinikai eredmények értékelésére az Oxford Shoulder Score-t (továbbiakban OSS) használtuk. Retrospektíve végeztük a vizsgálatot. Az OSS szubjektív teszt, amely a betegek nyugalmi és mozgás közbeni fájdalmára, a mindennapi életvitelhez szükséges mozgások kivitelezhetőségére kérdez rá 12 kérdéssel. A betegeknek levélben küldtük ki a kérdőívet. Akitől nem kapunk választ azokat telefonon, vagy email-ben sikerült elérni, mind a huszonhét betegünket sikerült megkérdeznünk. $\mathrm{Az}$ elérhető 60 ponthoz képest átlagosan 52,5 pontos kiváló eredményt kaptunk. A Rockwood III-as típusnál 50,6 ( $n=6)$, IV-es típusnál 53,1 ( $n=10)$, az V-ös esetében 52,1 ( $n=11)$. Ez alapján kimondhatjuk, hogy nem találtunk szignifikáns különbséget a klinikai eredményben a három Rockwood (III-IV. és V.) csoport között, az elért funkciót nem befolyásolta a dislocatio mértéke. A fenti két betegnél jóval szerényebb értékeket értünk el, 33 és 35 pontot. Sebgyógyulási zavar, szeptikus szövődmény, hypertrophiás hegesedés, keloid képződés nem volt. A fentebb említett két beteg kivételével minden páciens elégedett volt a mútétet követően, és legkésőbb két hónap után vissza tudott térni korábbi munkájához.
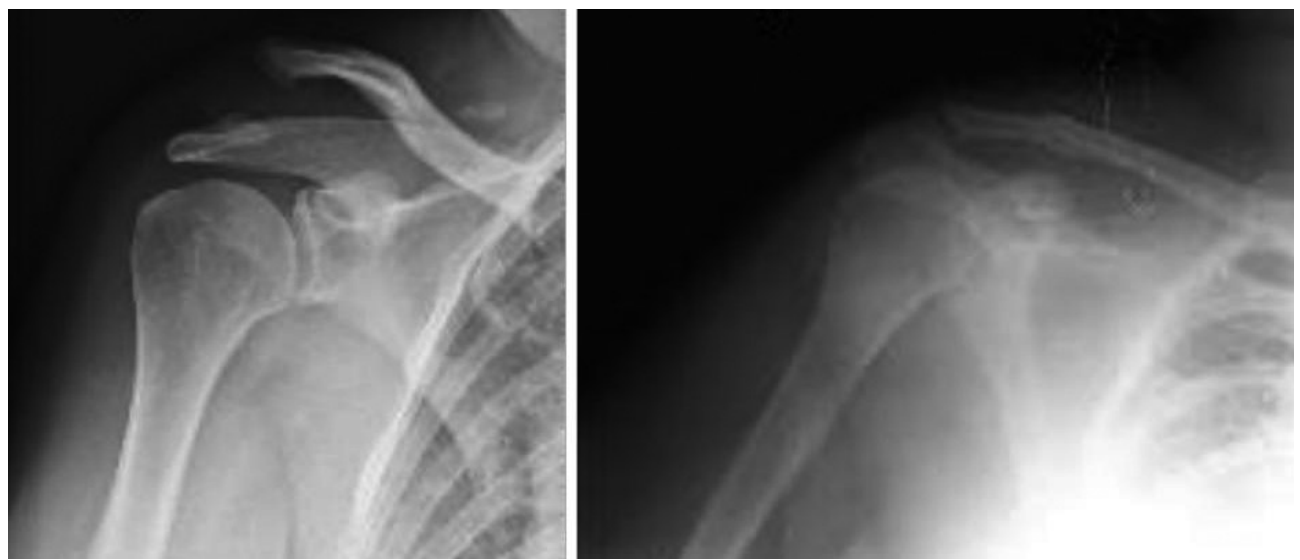

5. ábra Rockwood V. típus, mütét előtti és posztoperativ felvétel
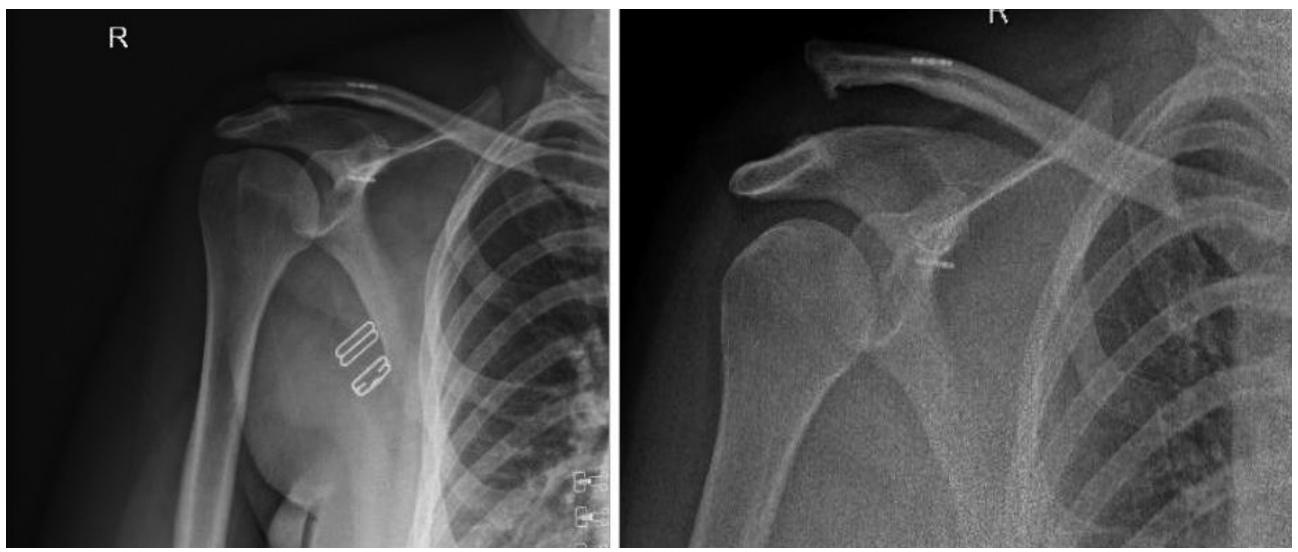

6. ábra Elmozdulás a posztoperativ 2. és 4. hónap után 

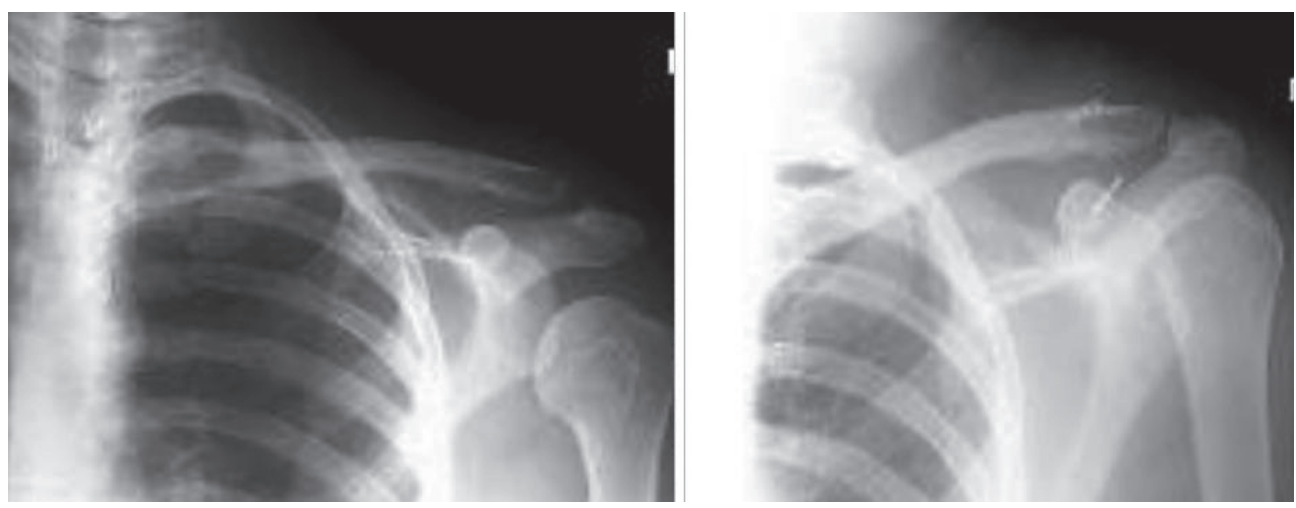

7. ábra Pre-és posztoperatív röntgenfelvétel
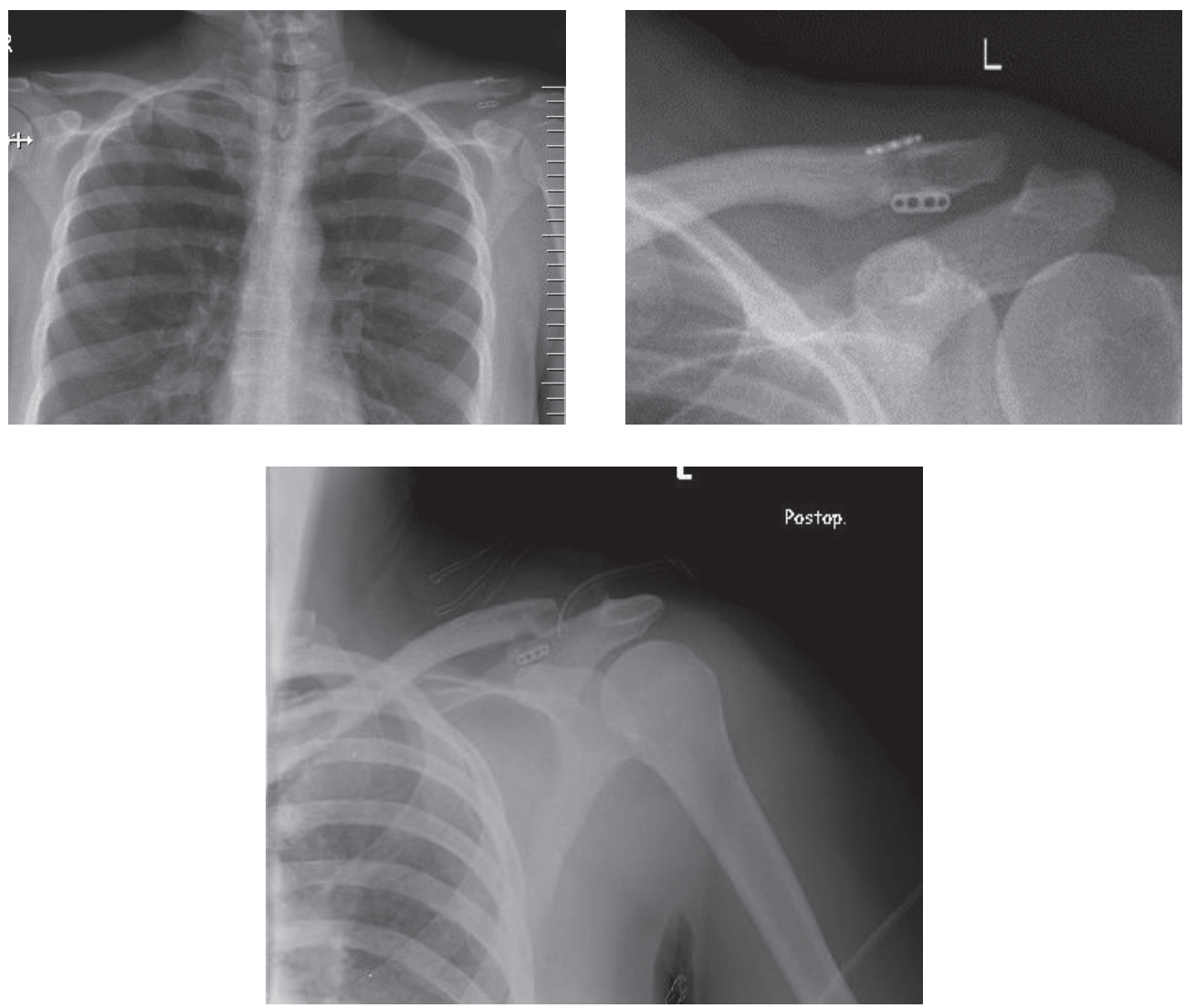

8. ábra Endobutton a clavicula alá csúszott, subluxált helyzet alakult ki, majd clavicula vég reszekció történt 


\section{MEGBESZÉLÉS}

Ahogy már korábban említettük, az AC ficamok mútéti ellátása nem teljesen megoldott, a számtalan mútéti eljárás is arra utal, hogy még nem találták meg az optimális technikát. A régóta alkalmazott módszerek mellett viszonylag sok volt a szövődmény, sikertelenség. Valószínúleg ennek tudható be, hogy az utóbbi években egyre több közlemény jelent meg a dinamikus coracoclavicularis rögzítést biztosító rendszerekkel, így a MINAR-ral kapcsolatban is. Aburto-Bernardo és munkatársai a miénkhez képest körülbelül fele esetszám mellett hasonlóan kiváló eredményekről számoltak be (1). Katsenis és munkatársai 50 MINAR-ral elvégzett acromioclavicularis rekonstrukció után szintén nagyon jó eredményeket közöltek (5). Nem találtak szignifikáns különbséget a klinikai és radiológiai eredményben a Rockwood III-IV-V csoportok között. Ezt a mi vizsgálatunk is igazolta. Egyáltalán nem, vagy csak 1-2 esetben írtak le gyulladásos szövődményt. A klinikai eredmények objektivizálásához többnyire OSS, Constant Score, Imatami Test Score rendszereket használtak.

Egyik célkitűzésünk az volt, hogy anatómiai rekonstrukciót tudjunk végezni, megtartva az AC ízület dinamikáját. A behelyezett implantátum kellően erősnek bizonyult, emberi erővel szinte elszakíthatatlan, jól pozícionálva stabil, de a szükséges rotációs mozgást engedi, biomechanikai szempontból ideális. A betegek panaszai hamar csökkentek, a 3-4 hetes immobilizáció sokszor a panaszmentesség miatt hosszúnak is bizonyult. A vállízület mozgásai hamar visszatértek. A betegek rehabilitációja szinte azonnal megkezdhető, szemben a többi rigid rögzítési formával (tűzés, húzóhurok, Bosworth csavar). Mindkét problémás esetünk a kezdeti időszakban fordult elő. Az első beteg első vizsgálata során a sérülést a Rockwood II. típusba soroltuk, és konzervatív kezelést indítottunk. A beteg állapotromlása, jól látható AC ízületi deformitás miatt, a két héttel később készített kontroll röntgenfelvételen már Rockwood V. dislocatio ábrázolódott, ezután került sor a mútétre. A posztoperatív felvételen a clavicula helyén áll, az implantátum helyzete megfelelő. A későbbi, 2 és 4 hónap múlva készült felvételeken egyre fokozódott a dislocatio, miközben az endobuttonok helyzete nem változott. A fonál elszakadt, a coracoclavicularis szalagoknak megfelelően teherbíró kötőszövetes, szalagos rögzülés nem alakult ki. A másik kázus egyértelmúen mútéttechnikai hiba következménye. A helytelenül pozicionált endobutton a fúrt lyukon át visszacsúszott, a clavicula alá került, ezáltal funkcióját vesztette. Más kérdés, hogy ezt követően reluxatio nem jött létre. A beteg továbbra is fennálló panaszainak oka valószínúleg a korai AC ízületi arthrosis.

A „learning curve” után a mútéteket szövődmény nélkül, eredményesen végeztük. A mútéteket több, minden esetben tapasztalt traumatológus szakorvos végezte, de nem volt kritérium váll artroszkópiában való jártasság. Az ehhez használt teljes MINAR instrumentárium és FLIPPTACK-set kellő segítséget nyújt, elegendő gyakorlat után a mútéti idő jelentősen lerövidült, a mútét biztonságosan elvégezhető. A modern kor követelményeinek megfelelően a MINAR mútét valóban minimálisan invazív, 4-5 cm-es feltárásból kivitelezhető. Implantátum eltávolítás nem szükséges, a fenti két eset kivételével nem is végeztünk. Röntgen sugárterhelés minimális, vagy nincs. Ennyi előnyös tulajdonsága mellett egyetlen hátránya az implantátum és az eszközpark magas ára.

Úgy gondoljuk, hogy a hazai és nemzetközi irodalmi adatok és a saját anyagunk eredményei alapján mindenképpen meggyőző, ajánlható mútéti technika. Ahogy erre cikkünkben már említést tettünk, egyelőre nem ez az egyetlen alkalmazott technika osztályunkon az acromioclavicularis ízület rekonstrukciójára, ezért a későbbiekben tervezünk egy prospektív randomizált study-t lefolytatni a különböző módszerek összehasonlítására. 


\section{IRODALOM}

1. Aburto-Bernardo M., Muñoz-Jiménez A., Igualada-Blázquez C., Mediavilla-Santos L., Vaquero-Martín J.: Minimally invasive surgical treatment of acromioclavicular dislocations. Acta Ortop. Mex. 2011. 25. (6): 359-365.

2. Bjerneld H., Hovelius L., Thorling J.: Acromio-clavicular separations treated conservatively. A 5-year follow-up study. Acta Orthop. Scand. 1983. 54. (5): 743-745. https://doi.org/10.3109/17453678308996622

3. Ceccarelli E., Bondi R., Alviti F., Garofalo R., Miulli F., Padua R.: Treatment of acute grade III acromioclavicular dislocation: a lack of evidence. J. Orthop. Traumatol. 2008. 9. (2): 105-108. https://doi.ora/10.1007/s10195-008-0013-7

4. Fukuda K., Craig E. V., An K. N., Cofield R. H., Chao E. Y.: Biomechanical study of the ligamentous system of the acromioclavicular joint. J Bone Joint Surg Am. 1986. 68. (3): 434-440. https://doi.org/10.2106/00004623-198668030-00019

5. Katsenis D. L., Stamoulis D., Begkas D., Tsamados S.: Minimally invasive reconstruction of acute type IV and Type V acromioclavicular separations. Orthopedics. 2015 Apr;38(4):e324-30. 2015. 38. (4): e324-30.

6. McPhee I. B.: Inferior dislocation of the outer end of the clavicle. J Trauma. 1980. 20. (8): 709-710. https://doi.org/10.1097/00005373-198008000-00015

7. Mouhsine E., Garofalo R., Crevoisier X., Farron A.:Grade I and II acromioclavicular dislocations: results of conservative treatment. J. Shoulder Elbow Surg. 2003. 12. (6): 599-602. https://doi.org/10.1016/S1058-2746(03)00215-5

8. Nissen C. W., Chatterjee A.: Type III acromioclavicular separation: results of a recent survey on its management. Am. J. Orthop. (Belle Mead NJ). 2007. 36. (2): 89-93.

9. Norell H. Jr., Lewellyn R. C.: Migration of a threaded Steinmann pin from an acromioclavicular joint into the spinal canal. A case report. J Bone Joint Surg Am. 1965. 47: 1024-1026. https://doi.org/10.2106/00004623-196547050-00012

10. Petersen W, Wellmann M, Rosslenbroich S, Zantop T.: Minimally Invasive Acromioclavicular Joint Reconstruction (MINAR). Oper. Orthop. Traumatol. 2010. 22. (1): 52-61. https://doi.org/10.1007/s00064-010-3004-4

11. Rockwood C. A., Williams G.. R., Youg D. C.: Disorders of the acromioclavicular joint. In: Rockwood C. A., Masten. F. A. (Eds): The shoulder. 3. ed. Philadelphia: WB Saunders, 2004. 521-595. p.

12. Shaw M. B, McInerney J. J, Dias J. J, Evans P. A.: Acromioclavicular joint sprains: the post-injury recovery interval. Injury. 2003.34. (6): 438-442. https://doi.org/10.1016/S0020-1383(02)00187-0

13. Wellmann M., Zantop T., Weimann A., Raschke M. J., Petersen W.: Biomechanical evaluation of minimally invasive repairs for complete acromioclavicular joint dislocation. Am. J. Sports Med. 2007. 35. (6): 955-961. https://doi.org/10.1177/0363546506298585

14. Wellmann M., Zantop T., Petersen W.: Minimally invasive coracoclavicular ligament augmentation with a flip button/ polydioxanone repair for treatment of total acromioclavicular joint dislocation. Arthroscopy. 2007. 23. (10): 1132.e1-5. https://doi.org/10.1016/i.arthro.2006.12.015

15. Zolczer L., Nemes Gy., Manninger J.: A kulcscsont laterális végének alsó, subcoracoidális ficama. Magy. Traumatol. Orthop. Helyreállító Seb. 1973. 16. (1): 46-48.

\section{Dr. Szabó Szabolcs}

B-A-Z. Megyei Kórház és Egyetemi Oktató Kórház Traumatológiai Osztály

3526 Miskolc Szentpéteri kapu 72-76.

szabszabi78@gmail.com 